\title{
Renal impairment in myeloma: negative association with isoelectric point of excreted Bence-Jones protein
}

\author{
A G W NORDEN, * F V FLYNN, * L M FULCHER, * J D M RICHARDS \\ From the Departments of *Chemical Pathology and Haematology, University College Hospital, London
}

SUMMARY The isoelectric point (pI) of the major form of Bence-Jones protein excreted by 62 patients with myeloma and six with macroglobulinaemia was measured by combining isoelectric focusing with immunoblotting techniques. The distribution of the pI values for both $\kappa$ and $\lambda$ type proteins was bimodal, most falling in the ranges 5.0-6.0 and 7.0-7.5. Plasma creatinine and creatinine clearance and the urine excretion of $\alpha-1$-microglobulin and $\beta-2$-microglobulin were measured in 24 of the patients. These patients, who were free of additional factors known to have an association with the development of renal impairment, were followed up for a mean period of 16 months (range three to 28 months). It was found that renal impairment was not related to the pI of the Bence-Jones protein excreted.

Although the occurrence of Bence-Jones proteinuria in patients with myeloma is strongly associated with renal failure,' the development of renal impairment is not predictable, and in some cases Bence-Jones protein may continue to be excreted with minimal renal malfunction..$^{1-3}$ Other features of the disease such as hypercalcaemia, or the use of nephrotoxic drugs, may be responsible for this complication.

It has been proposed that the physical properties of the Bence-Jones protein are important in determining whether renal impairment develops. ${ }^{14}$ Thus it has been claimed that Bence-Jones proteins of relatively high isoelectric point (pI) are more likely to be associated with renal impairment than those of low pI and it has been suggested that this might be due to a strong ionic interaction with the acidic Tamm-Horsfall glycoprotein (pI 3.5) or other tubular proteins at the pH occurring within the renal tubule. ${ }^{14}$ Such interactions might lead to cast formation or tubulopathy and eventually glomerular failure. The combined evidence from animal models ${ }^{46}$ and clinical studies, ${ }^{7-9}$ however, is contradictory.

We recently developed a method, combining isoelectric focusing and immunoblotting, which permits the direct measurement of the pI of BenceJones proteins. ${ }^{10}$ This new procedure has the major advantage that preliminary concentration, electrophoresis, or liquid chromatography of the urine speciman is unnecessary. ${ }^{78}$ Using this technique we investigated the association between the pI values of

Accepted for publication 11 July 1988
Bence-Jones proteins and several indices of both glomerular and tubular function.

\section{Patients and methods}

Sixty two patients with myeloma and six with macroglobulinaemia were studied. All were excreting Bence-Jones protein and all those with myeloma fulfilled the diagnostic criteria used in the first United Kingdom myelomatosis trial organised by the Medical Research Council." "Twenty four patients were studied sequentially in more detail; these were selected by exclusion of those with some additional complicating factor that could predispose to the development of renal impairment, and by eliminating those who had a history of renal disease before developing myeloma. The former exclusions included patients with hypercalcaemia, hyperuricaemia, or hypercalciuria, either before or after rehydration. Those who had begun chemotherapy were also excluded, apart from six who had received a dose well below that reported as causing renal impairment: these six patients had received only one or two of the usual nine courses of a standard regimen which comprised melphalan $(0.25 \mathrm{mg} / \mathrm{kg} /$ day $)$ and prednisolone ( $1 \mathrm{mg} / \mathrm{kg} /$ day) for four days every six weeks.

The pI of the major Bence-Jones protein excreted, the plasma creatinine and creatinine clearance, and the urinary excretion of $\alpha-1$-microglobulin and $\beta-2$ microglobulin were measured. The reciprocal of the plasma creatinine concentration change each month and the changes in the urinary excretion of $\alpha-1$ - 


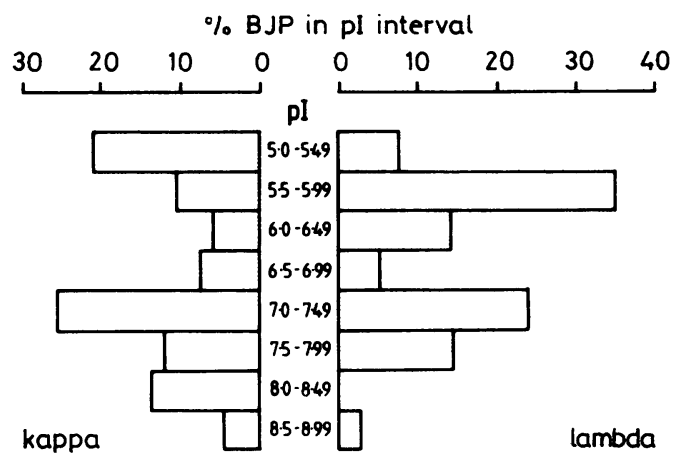

Fig 1 Frequency distribution of $\mathrm{pI}$ values of Bence-Jones proteins in 62 patients with myeloma and six with macroglobulinaemia.

microglobulin and of $\beta$-2-microglobulin each month were used as indices of the progression of renal impairment. The mean interval between presentation and the repeat measurements was 16 months (range three to 28 months).

Collection of urine and plasma specimens and

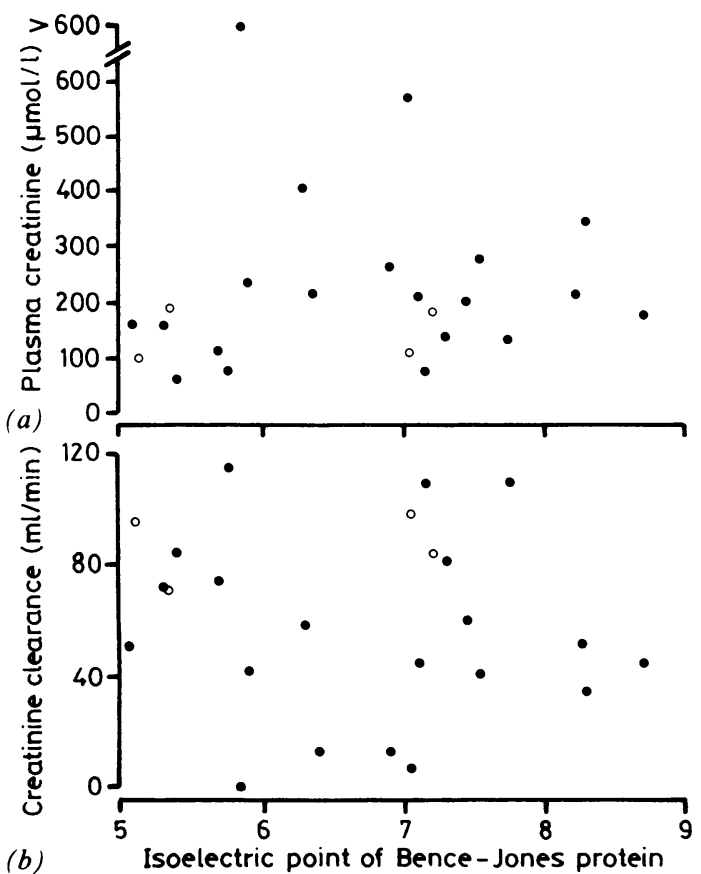

Fig 2 (a) Plasma creatinine concentrations, and (b) creatinine clearances and the pI of Bence-Jones proteins in 24 patients with myeloma lacking a recognised cause for renal impairment. Open circles refer to patients graded as having a one-plus quantity of Bence-Jones protein and dark circles to patients with two- to three-plus Bence-Jones protein excretion.
Norden, Flynn, Fulcher, Richards

measurement of the pI values of the Bence-Jones proteins were performed as described previously. ${ }^{10} 12$ Bence-Jones protein excretion was estimated semiquantitatively by applying a volume of urine containing $25 \mathrm{nmol}$ creatinine to the isoelectric focusing gels and using a previously described scoring system. ${ }^{1012}$

Two dimensional isoelectric focusing and electrophoresis was carried out using pI 3-10 ampholytes according to Pharmacia Application Note No 521464-00-04 (Pharmacia Ltd, Central Milton Keynes, Buckinghamshire). Such gels were immunoblotted as described previously. ${ }^{10}$

Alpha-1-microglobulin was measured by solidphase enzyme immunoassay using "Imzyme alpha1-m" reagents (Diamed Diagnostics Ltd, Bootle, Merseyside). Beta-2-microglobulin was quantitated by the "Beta-2-micro" kit (Pharmacia). Creatinine was determined in plasma by an end point alkaline picrate method using a "SMAC" Analyzer (Technicon Ltd, Basingstoke, Hampshire), and in urine by a rate reaction alkaline picrate method using an "Astra" analyser (Beckman Ltd, High Wycombe, Buckinghamshire).

\section{Results}

The frequency distribution of the measured $\mathrm{pI}$ values of the major form of Bence-Jones protein excreted by the 68 patients with myeloma or macroglobulinaemia

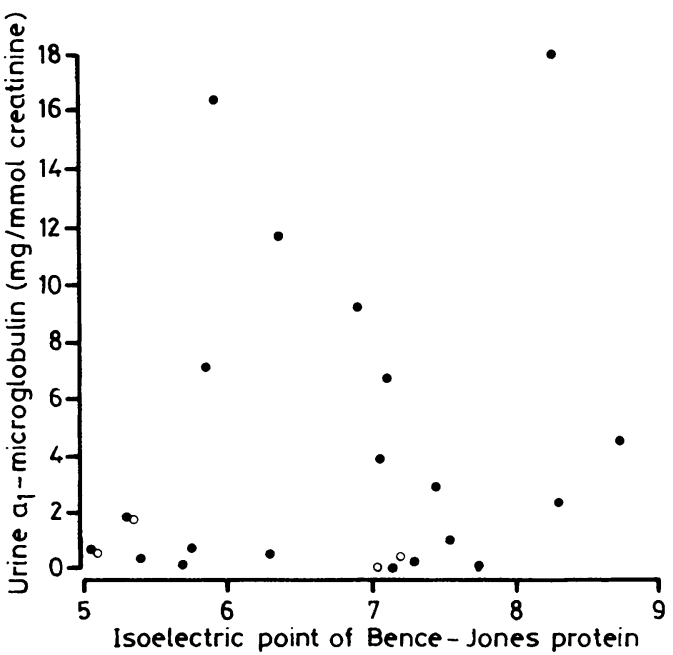

Fig 3 Association between urine $\alpha-1-$ microglobulin excretion in $\mathrm{mg} / \mathrm{mmol}$ creatinine and $\mathrm{pI}$ of the Bence-Jones protein in 24 patients with myeloma lacking a recognised cause for renal impairment. Symbols are the same as those in fig 2. 


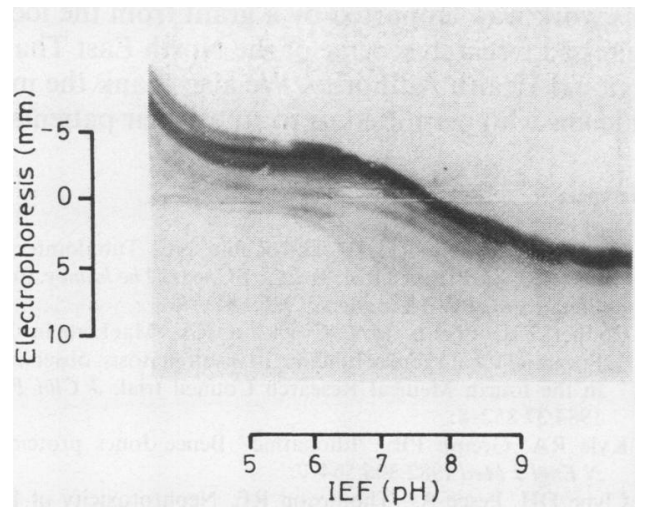

Fig 4 Immunoblot of a urine specimen subjected to two dimensional isoelectric focusing and electrophoresis on agarose gel and stained for $x$ light chains. pI of principal form of $\kappa$ Bence-Jones protein is $\mathbf{7 \cdot 7 5}$.

is shown in fig 1 . This shows a bimodal distribution for both $\kappa$ and $\lambda$ type Bence-Jones proteins, with pI values of 5.0-6.0 and 7.0-7.5 being the most common.

In figs $2 a$ and $b$ the plasma creatinine and creatinine clearance values, obtained at the time of presentation in the 24 patients lacking an additional recognised cause for renal impairment, are shown plotted against the pI values of the corresponding Bence-Jones proteins. These show no correlation between the variables, regardless of the quantity of Bence-Jones protein being excreted.

In fig 3 the quantities of $\alpha$-1-microglobulin excreted by the 24 patients lacking an additional recognised cause for renal impairment are shown plotted against

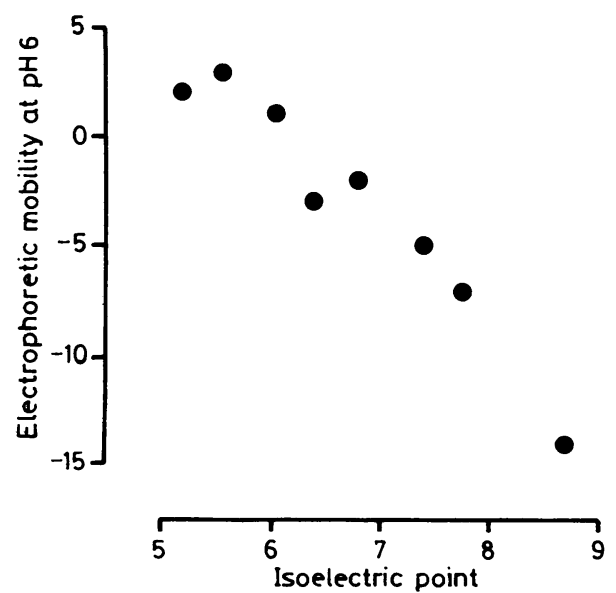

Fig 5 Association between electrophoretic mobility at pH 6 and $p I$ of four $\kappa$ and four $\lambda$ Bence-Jones proteins. Negative values for mobility reflect movement towards cathode. the pI values of the major Bence-Jones protein excreted. This shows no correlation between the two measurements. Absence of any correlation was also found when patients with plasma creatinine concentrations greater than $200 \mu \mathrm{mol} / 1$ were omitted. A similar negative finding was obtained in relation to the quantity of $\beta$-2-microglobulin being excreted.

When the rate of change in the reciprocal of the plasma creatinine and in the excretion of $\alpha-1-$ and $\beta-2$ microglobulins was examined in relation to the pI values of the Bence-Jones proteins, no significant correlations were detected.

When we measured the electrophoretic mobility of eight Bence-Jones proteins over a $\mathrm{pH}$ gradient, using isoelectric focusing and electrophoresis performed at right angles to one another (fig 4), we found a good correlation between the electrophoretic mobility of the proteins at $\mathrm{pH} 6$ and the $\mathrm{pI}$ of the protein (fig 5).

\section{Discussion}

There have been two previous studies of the association between the pI of Bence-Jones proteins and the development of renal impairment in patients with myeloma. Coward et al found that the occurrence of Bence-Jones protein with a high pI had a definite correlation with reduced creatinine clearance. ${ }^{7}$ More recently, Johns et al reported that proximal tubular function, as measured by the urinary $\alpha-1$ microglobulin content, was more severely impaired in patients excreting Bence-Jones protein of high pI value, but that there was no association with the serum creatinine concentration. ${ }^{8}$ We have not confirmed either of the positive associations reported in these studies. It may be important that both these groups of authors used less direct approaches to pI measurement than ourselves; nevertheless, it is unlikely that electrophoresis after preliminary concentration of the urine ${ }^{7}$ or fast protein liquid chromatography ${ }^{8}$ would bias the pI measurements in relation to the presence or absence of renal impairment. It is more likely that different criteria used for the selection of patients, unsuspected heterogeneity in the aetiology of renal impairment, or chance bias in population sampling contributed to the different findings.

In the context of the possible nephrotoxicity of some Bence-Jones proteins three criticisms of the relevance of in vitro pI measurements are apparent. First, the pI is not the critical variable in a charge-related hypothesis of nephrotoxicity; it is net charge at the $\mathrm{pH}$ prevailing at the site of toxicity that should matter. Nevertheless, some difference in nephrotoxicity ought to be seen between Bence-Jones proteins with pIs within or above the physiological limits of in-vivo $\mathrm{pH}$. Secondly, the association between pI values measured in agarose gels containing ampholytes and those 
prevailing in the kidney is unknown. Thirdly, it is uncertain whether charge interactions between BenceJones proteins and renal tissue or urine constituents will be clinically important at the $\mathrm{pH}$ values and ionic strengths prevailing within the renal tubule.

We measured electrophoretic mobility at $\mathrm{pH} 6$ to provide an indication of the charge carried by BenceJones proteins. The good correlation we found between this mobility and the pI of the proteins suggests that the $\mathrm{pI}$ provides a good measure of net charge at a physiological $\mathrm{pH}$ and that $\mathrm{pI}$ measurements are relevant to the testing of a chargebased hypothesis of the nephrotoxicity of Bence-Jones proteins. In this context it is of interest that Hill et al found that there was an excellent correlation between decreasing electrophoretic mobility of the light chain protein excreted and increasing serum urea concentration among 17 patients with myeloma and BenceJones proteinuria.' This association was attributed to the effects of the charge of the molecule on either its polymerisation or the quantity that could be filtered at the glomerulus. Unfortunately, the $\mathrm{pH}$ at which they measured the electrophoretic mobility of the light chains was not specified.

A fundamental difficulty complicating the interpretation of all the studies that have attempted to relate the charge on Bence-Jones proteins to nephrotoxicity is that the quantity of Bence-Jones protein reaching the renal tubule is unknown. As has been pointed out by Rosansky et al it is not valid to assume that the amount excreted can be directly related to the quantity entering the glomerular filtrate. $^{13}$

Interest in the pI of Bence-Jones proteins was stimulated by in vitro studies of nephrotoxicity. ${ }^{4}$ Other investigations, such as those of light chain polymerisation, ${ }^{14}$ have failed to show physical properties which might affect nephrotoxicity. If physical characterisation of Bence-Jones proteins permitted the identification of a subgroup of patients at particular risk of developing renal impairment, such patients could be given intensive prophylaxis. A study such as this cannot prove that the net charge on a Bence-Jones protein is unimportant in the processes which underlie renal impairment, but our findings do suggest that the $\mathrm{pI}$ of the protein is a poor clinical guide.
This work was supported by a grant from the locally organised research scheme of the North East Thames Regional Health Authority. We also thank the many clinicians who permitted us to study their patients.

\section{References}

1 Cotran RS, Rubin RH, Tolkoff-Rubin NE. Tubulointerstitial diseases. In: Brenner BM, Rector FC, eds. The kidney. 3rd ed. Philadelphia: WB Saunders, 1986;1143-73.

2 Cooper EH, Forbes MA, Crockson RA, MacLennan ICM. Proximal renal tubular function in myelomatosis: observations in the fourth Medical Research Council trial. J Clin Pathol 1984;37:852-8.

3 Kyle RA, Greipp PR. "Idiopathic" Bence Jones proteinuria. N Engl J Med 1982;306:564-7.

4 Clyne DH, Pesce AJ, Thompson RE. Nephrotoxicity of Bence Jones proteins in the rat: importance of protein isoelectric point. Kidney Int 1979;16:345-52.

5 Weiss JH, Williams RH, Galla JH, et al. Pathophysiology of acute Bence-Jones protein nephrotoxicity in the rat. Kidney Int 1981;20:198-210.

6 Smolens P, Venkatachalam M, Stein JH. Myeloma kidney cast nephropathy in a rat model of multiple myeloma. Kidney Int 1983;24:192-204.

7 Coward RA, Delamore IW, Mallick NP, Robinson EL. The importance of urinary immunoglobulin light chain isoelectric point (pI) in nephrotoxicity in multiple myeloma. Clin Sci 1984;66:229-32.

8 Johns EA, Turner R, Cooper EH, MacLennan ICM. Isoelectric points of urinary light chains in myelomatosis: analysis in relation to nephrotoxicity. J Clin Pathol 1986;39:833-7.

9 Hill GS, Morel-Maroger L, Mery J-P, Brouet JC, Mignon F. Renal lesions in multiple myeloma: their relationship to associated protein abnormalities. Am J Kidney Dis 1983;11: 423-8.

10 Norden AGW, Fulcher LM, Flynn FV. Detection of Bence-Jones protein by isoelectric focussing of unconcentrated urine followed by nitrocellulose blotting and immunoperoxidase staining. Clin Chim Acta 1985;153:149-56.

11 Medical Research Council. Report of the first myelomatosis trial: 1. Analysis of the presenting features of prognostic importance. Br J Haematol 1973;24:123-39.

12 Norden AGW, Fulcher LM, Flynn FV. Immunoglobulin lightchain immunoblots of urine proteins from patients with tubular and Bence-Jones proteinuria. Clin Chim Acta 1987;166:307-15.

13 Rosansky SJ, Sartiano GP, Lynch B, Gonzales F. Valdivieso J. Bence-Jones proteinuria. $N$ Engl J Med 1982;307:1026-7.

14 Solling K, Solling J, Lanng Nielsen J. Polymeric Bence-Jones proteins in serum in myeloma patients with renal insuffciency. Acta Med Scand 1984;216:495-502.

Requests for reprints to: Professor F V Flynn, Department of Chemical Pathology, University College Hospital, Gower Street, London WC1E 6AU, England. 